\title{
Determinants of farmers' willingness to export yam in Ibara- pa East and Ibarapa Central Local Government Areas of Oyo State, Nigeria
}

\author{
O. F. ADESIYAN*, A. T. ADESIYAN \& L. ABISOYE \\ (O. F. A; A. T. A. \& L. A.: Department of Agricultural Economics, Obafemi Awolowo \\ University, Ile-Ife) \\ *Corresponding author's email: graceheritage2003@yahoo.com
}

\begin{abstract}
The study was carried out to determine the factors affecting farmer's willingness to export yam in Oyo State. This study used data collected from a multistage sampling of 80 yam farmers. Analytical techniques used include descriptive statistics and probit model. The results showed that majority of farmers in the study area are ageing, with a mean age of 57.21 . It was also observed that there were more males $(87.5 \%)$ than females $(12.5 \%)$ and that $71.2 \%$ of farmers had formal education. The result of probit analysis showed that farm size $(0.81, p=0.002)$ was a significant factor determining the willingness of farmers to export. This means as the farmers' farm size increases so also is their willingness to export. The result also revealed that an increase in other occupation $(0.96, \mathrm{p}=0.154)$ of the respondents will bring about an increase in their willingness to export yam. This suggests that farmers who had other sources of income might be more willing to export yam. It was therefore concluded that when more land is allocated to yam production and financial support is made available to farmers in the study area, their willingness to export yam would increase.
\end{abstract}

Keywords: Determinants; Yam; Export; Willingness; Oyo State

Original scientific paper. Received 10 Jul 2018; revised 04 Mar 2020

\section{Introduction}

Yam is a tropical crop in the genus Dioscorea. It has 600 species out of which six are economically important staple species. These are Dioscorea rotundata (white guinea yam), Dioscorea alata (water yam), Dioscorea bulbifera (aerial yam), Dioscorea esculentum (Chinese yam) and Dioscorea dumetorom (trifoliate yam). Out of these, Dioscorea rotundata (white yam) and Dioscorea alata (water yam) are the most common species in Nigeria. Yams are grown in the coastal region in rain forests, wood savanna and southern savanna habitats
(Pius \& Odjuvwuedhrie, 2006). Yam is in the class of roots and tubers which is a staple of the Nigerian and West African diet that provides about 200 calories of energy per capita daily. In many yam producing areas in Nigeria, it is usually said that "yam is food and food is yam." It also has an important social status in gatherings and religious functions, which is assessed by the size of yam holdings one possesses.

Nigeria is the world's largest producer of yams, accounting for over $60 \%$ of the world production. According to the Food and Agriculture Organisation report (FAO) (2019),

Ghana Jnl Agric. Sci. 55 (1), 54 - 64

GJAS is an Open Access Journal and distributed under the terms of the Creative Commons (CC) License [CC BY 4.0] 
Nigeria produced 8 million tonnes per hectare of yam, representing about $66 \%$ of total yam production in the World and about $66.8 \%$ in Africa in the year 2017. Table 1 shows the output of yam from 1997 to 2017. From the Table, it can be observed that the output of yam has not been increasing substantially over the years. This might be due to the low returns from the business which could have led to resource reallocation away from yam production to other cropping systems. According to Inside Tax (2015), an export promotion incentive scheme was initiated in Nigeria. Under the scheme, some staple food crops such as yam, maize, cassava, and beans were de-listed from the export prohibition list. In a determined effort to further boost domestic production and expand exports, an export subsidy of $10 \%$ on agricultural commodities was introduced in 2003 and this remains in operation presently. Available records show that the Nigerian government exported 72 metric tonnes of yam in 2018 (Olomola \& Nwafor, 2018)

In Nigeria, agricultural exports have played a major role in economic development by providing the needed foreign exchange earnings for other development projects. From the initial trade in palm oil, Nigeria's agricultural export has expanded to include palm kernel and cocoa beans. Available statistics indicate that in 1960, agricultural export commodities contributed over $75 \%$ of total merchandise export (Ekpo \& Egwaikhide, 1994). The impact of commodity export on household income cannot be overemphasized. Besides assuring a stable flow of income and improving the farm family welfare conditions, it also provides an incentive for production among other things.
TABLE 1

Yam production quantities in Nigeria from 1997 to 2017

\begin{tabular}{ll}
\hline Year & Tonnes \\
\hline 1997 & $23,972,000$ \\
1998 & $24,768,000$ \\
1999 & $25,873,000$ \\
2000 & $26,201,000$ \\
2001 & $26,232,000$ \\
2002 & $27,911,000$ \\
2003 & $29,697,000$ \\
2004 & $31,776,000$ \\
2005 & $34,000,000$ \\
2006 & $36,720,000$ \\
2007 & $31,136,000$ \\
2008 & $35,017,000$ \\
2009 & $29,091,980$ \\
2010 & $37,328,180$ \\
2011 & $33,134,172$ \\
2012 & $32,318,900$ \\
2013 & $35,618,420$ \\
2014 & $45,151,589$ \\
2015 & $45,677,939$ \\
2016 & $49,384,352$ \\
\hline
\end{tabular}

Source: Federal Office of Agriculture Statistics, 2019

With an increase in agricultural production, food sustainability can beguaranteed and abundant availability of raw material which will, in turn, stimulate industrial growth and an increased Gross Domestic Product (GDP). Trading Economics (2019) observed that Nigeria's export earnings from m0ajor crops contributed significantly to the GDP. Similarly, the International Conference on E-Business and E-Government (2010) observed a long-term relationship between agricultural export and economic growth in Nigeria.

Though yam production has been in abundance, farmers are yet to look beyond the domestic market and seek opportunities in the international market. 
Since the seminar contribution of Bernard and Jensen (1995) and Okwu et al. (2013). Several studies have found that exporters perform better than non-exporters. In general, exporting firms are larger, more capital intensive, pay higher wages, hire more skilled workers, and most importantly, they are more productive than non-exporters (Clerides et al., 1998; Bernard \& Jensen, 1999; 2004b; Girma et al., 2004; Bernard et al., 2007, Ana -Tavarese et al., 2015). According to Adesiyan (2011), farmers' livelihood can be improved if they trade yam or its product outside Nigeria. It has been argued that the economic development of any nation has a strong relationship with the export performance of the country. World Bank (2017) noted that the economic problems faced by most countries, at a given period, were associated with export marketing of the nations.

Findings from Stephen Morse (2018) revealed that yam farmers are no more showing interest in adopting new yam technologies as a result of the low returns from the product which could be improved through trading yam at international markets. Studies have found out that geography plays an important role on firms' export behavior (Bangmarigu, 2018) and other factors that could support or discourage willingness to export yam are yet to be unraveled. This study, therefore, aims to analyse the factors affecting farmers' willingness to trade yam internationally. This study is necessary because it probes into the factors affecting the willingness of farmers to export yam, and how resource allocation is best achieved for policy support towards export trade. Findings from this study are helpful to yam producers in overcoming the problem of low income and poverty. For a nation that ranks first in the world in terms of production, this might just be the beginning of another sad story for a very prom- ising enterprise. With an increase in the real income, the welfare of farmers is sure to increase which will also give incentive to farmers to boost production thereby making yam readily available in the domestic market whether for direct consumption or as raw materials for industrial use and also meeting with the first (No poverty) and second (Zero hunger) goals of the Sustainable Development Goals (SDGs).

In analyzing this objective, discrete choice models are normally used. Discrete choice analysis involves situations in which the dependent variable is a qualitative response (i.e., choice among finite set of alternatives) rather than a continuous mathematical measure as in ordinary regression. The primary task in such cases is to specify and estimate a model that would explain the probability of occurrence of the qualitative response and qualitative responses depends on the range of possible values for the dependent variable. Binary choice models can be applied in situations where the possible outcomes for the dependent variable are dichotomous (e.g., a yes or no). On the other hand, when the qualitative response has a probability of occurrence over a range exceeding two options, multinomial choice models are suitable (Sandro, 2014).

The choice set is considered to be mutually exclusive, collectively exhaustive and finite (Sandro, 2014). Mutual-exclusivity means that the choice alternatives must be distinct so as to allow respondents to compare all alternatives provided in a choice set and be able to show unique preference for each alternative, but pick one and only one in each choice task. The exhaustiveness property implies that the choice set must include a full range of alternatives over which a typical respondent would be expected to express preference. Moreover, the finiteness requirement addresses the practi- 
cality of the choice situation, by ensuring that each respondent is provided with a manageable number of alternatives and choice sets.

Stock and Watson (2006) suggest that the logistic approach was traditionally preferred since the function does not involve the evaluation of an integral and thus model parameters could be estimated faster. However, this argument is no longer relevant given the computational speed now achievable and choice of one specification rather than the other is now usually arbitrary.

Logistic regression uses categorically explained variables (Kollár, 2014). The aim of logistic regression (it is similar to the linear regression) is expressed dependence of magnitude $\mathrm{Y}$ on the variable $\mathrm{X}_{\mathrm{k}}$. It does not use a linear dependence. Probit analysis is an alternative to the logit method. The main difference is that it assumes a normal distribution of random variables (independent variables in the model). The difference lies in the fact that logistic function has harder "fat tails" (distribution has more observations appearing at the end of the distribution function) while the distribution function of the probit model has a steeper slope. Both distribution function is almost linear between $\pi=0,2$ and $\pi=0,8$ (Majerčák \& Majerčáková, 2013). There are no significant differences in practice, only in the case, that sample contains numerous observations with extreme values. Parameters estimates obtained by logit and probit models cannot be compared directly because the logarithmic distribution has variance equal $\pi 2 / 3$, therefore the estimates obtained by logit model have to be multiplied by $31 / 2 / \pi$ in order to be comparable with estimates obtained in the probit model (Lehútová, 2011).

Logit model is a method for fitting a set of data when the response variable consists of proportions or binary coded data. Probit model is a type of binary classification model, which is more appropriate in fitting regression curve, when the response variable is a binary or dichotomous variable and the predictors are either numerical or categorical (Xu \& Long (2005); Lehutová (2011); Cisko \& Klieštik (2013); Majerčák \& Majerčáková (2013). Nimoh (2011) examined the interest of farmers and insurance companies in farm insurance. The sample consisted of 110 respondents; 100 farmers and 10 insurance companies. The Probit model was used to analyse the effect of factors affecting the willingness of cocoa farmers to accept farm insurance. All of the respondents had ever heard of one or more types of insurance whiles $32 \%$ had knowledge of farm insurance. About $87 \%$ indicated their interest in farm insurance. The t-statistic results showed that other occupations of farmer $(-0.200, p=0.097)$, farm size $(1.96, p$ $=0.050)$ and owner of land for farming $(-0.41$, $\mathrm{p}=0.011)$ significantly affected willingness to accept farm insurance policies. For a realistic farm insurance policy, it is recommended that land availability for farmers must be largely considered.

Lindblom et al. (2017) reported that the adoption of appropriate agricultural technologies is a requirement for sustainable agricultural development. The study of Lindblom et al. (2017) was conducted to investigate the adoption of Kalima, a newly introduced dry bean variety (Phaseolus vulgaris L.), by smallholder farmers in targeted rural areas in Malawi and to identify the factors that most strongly influenced farmers' willingness to adopt the variety. The main findings Lindblom et al. discovered were that Kalima was only grown by farmers who had received seed through seed multiplication groups and was not grown by farmers outside of those groups due to unavailability of seed. Farmers' gender, literacy level, and lev- 
el of education influenced their willingness to adopt Kalima, as did farmers' perceptions of specific bean characteristics such as yield, pest tolerance, pest susceptibility, bean color and cooking time. For adoption to be sustainable, information about technology should be judicious in order for farmers to form appropriate perceptions. To increase rates of adoption, the information should be delivered in a method suitable for farmers with a low literacy level.

\section{Materials and Methods}

The study was conducted in Ibarapa Central and Ibarapa East Local Government Area of Oyo State of Nigeria. The capital of Oyo State is Ibadan. It is bounded in the North by Kwara State in the East partly by Osun State and partly by Kwara state in the South by Ogun State and in the West by Benin republic. This State came into existence in 1976. The state runs an agrarian economy with a vast majority of the populace taking to farming. There are varieties of agricultural produce in the State. Multi-stage sampling technique was employed in selecting the samples needed for the study. At the 1st stage, purposive sampling technique was employed in the selection of Ibarapa Central and Ibarapa East Local Government Area, because yam producers are many in these areas. At the 2nd stage of selection, Igbo-Ora and Eruwa towns respectively were purposively selected because there seems to be more concentration of yam farmers in these areas. At the 3rd stage, 40 respondents were randomly selected from each town. This was done by collecting the list of farmers in these towns from the Agricultural Development Program (ADPs) under each LGA. In totality, 80 yam producers were selected.

The interview was carried out with the aid of a well-structured questionnaire consisting of some open-ended questions. The question- naire sought information on the socio-economic characteristics of the respondents such as gender, age, years of formal education, marital status, and family size. Farm characteristics such as farm size, total outputs, the geographical location of farmer's enterprise from major transport routes. Farmers' perception of yam exporting such as previous export experience, availability of transport facilities, profitability and worthiness of export, etc. were also included in the data collected during 2013/2014 cropping season. Probit model was employed to determine farmer's willingness to export yam. Probit model was credited to Gaddum (1933) and Bliss (1934). According to Nimoh (2011) because of the dichotomous nature of the dependent variable, normal regression model cannot be used to estimate the unknown parameters of the factors affecting farmers' willingness to export. The probit model is the most appropriate. The general probit model is expressed as:

$\mathrm{Y}=\beta_{0}+\beta \mathrm{iXi}+\mathrm{e} \ldots \ldots \ldots \ldots \ldots . .[1]$

Where $\mathrm{Y}$ is the dichotomous dependent variable expressed as

$Y=1$, if farmers are willing to export

$\mathrm{Y}=0$, if farmers are not willing to export

$\beta_{0}=$ Intercept

$\beta_{\mathrm{i}}=$ the regression coefficients that explains the probability of farmers to export

$\mathrm{X}_{\mathrm{i}}=$ Independent variables like age, gender, year of formal education, marital status which might affect farmers' willingness to export.

$\mathrm{e}=$ error term

Therefore, the empirical probit model is specified as:

$\mathrm{Y}=\beta_{0}+\beta_{1} \mathrm{X}_{\mathrm{i}}+\beta_{2} \mathrm{X}_{\mathrm{j}}+\beta_{3} \mathrm{X}_{\mathrm{k}} \ldots+\mathrm{e} \ldots[2]$

$\mathrm{X}_{\mathrm{i} 1 \ldots 10} \mathrm{X}_{\mathrm{j} 1 \ldots .5}, \mathrm{X}_{\mathrm{k} 1 \ldots 12}$

$X_{i}=$ personal characteristics, $X_{j}=$ farm characteristics, $X_{k}=$ perceived characteristics of innovation 


\section{$\mathbf{X}_{\mathrm{i}}=$ personal characteristics}

$\mathrm{X}_{\mathrm{i} 1}=$ Age of farmer (years), $\mathrm{X}_{\mathrm{i} 2}=$ sex i.e. male or female, $X_{i 3}=$ level of formal education, $X_{i 4}$ = finance $(\mathrm{N}), \mathrm{X}_{\mathrm{i} 5}=$ Marital status, $\mathrm{X}_{\mathrm{i} 6}=$ family size (number), $X_{i 7}=$ personal belief, $X_{i 8}=$ farming experience (years), $X_{i 9}=$ technological adoption, $\mathrm{X}_{\mathrm{i} 10}=$ other occupation

$X_{\mathrm{j}}=$ farm characteristics

$\mathrm{X}_{\mathrm{j} 1}=$ Geographical location of farm, $\mathrm{X}_{\mathrm{j} 2}=$ Farm size (hectares), $X_{j 3}=$ Exportable surplus per farmer $(\mathrm{kg}), \mathrm{X}_{\mathrm{j} 4}=$ Availability of transport facilities, $\mathrm{X}_{\mathrm{j} 5}=$ Storage facilities

$\mathbf{X}_{\mathbf{k}}=$ perceived characteristics of innovation $\mathrm{X}_{\mathrm{k} 1}=$ awareness, $\mathrm{X}_{\mathrm{k} 2}=$ profitability, $\mathrm{X}_{\mathrm{k} 3}=$ government restrictions, $X_{k 4}=$ exchange rates ( $\mathrm{X}_{\mathrm{k} 5}=$ interest rates $(\mathrm{N}), \mathrm{X}_{\mathrm{k} 6}=$ relative advantage, $X_{k 7}=$ contact with extension agents, $X_{k 8}$ $=$ cost of exportation $(\mathrm{N}), \mathrm{X}_{\mathrm{k} 9}=$ risk and uncertainty, $\mathrm{X}_{\mathrm{k} 10}=$ ease of exporting, $\mathrm{X}_{\mathrm{k} 11}=$ availability of reliable agent /distributor, $\mathrm{X}_{\mathrm{k} 12}=$ ability to meet quality and quantity on continuous basis

\section{Description of variables}

Y (Willingness): It describes the willingness of farmers to participate in export trade. It is the dependent variable. It is a dichotomous variable expressed as $\mathrm{Y}=1$, if farmers are willing to export, $Y=0$, otherwise.

$\mathbf{X}_{\mathrm{i} 2}$ (Gender): It refers to whether the farmer is either male or female.

$\mathbf{X}_{\mathrm{i} 3}$ (Education): A farmer is considered either literate or illiterate. The a priori expectation is positive. This is because a higher level of education can impact positively on the willingness of farmers to export.

$\mathbf{X}_{\text {is }}$ (Marital status): It refers to whether or not the farmer is married. It is believed that when the farmer is married he tends to have more responsibility which increases his/her need for a rise in income, which might help his willingness to export and when he is unmarried, he may be free to explore opportunities, since he has no one to cater for, so the $a$ - priori expectation i.e (the expectation of the signs of the coefficients based on economic theory) which is either positive (which means the explanatory or variables included in the model will increase or improve the dependent variable) or negative (which suggests a decrease effect of the explanatory variable on the dependent variable).

$\mathbf{X}_{\mathrm{i} 6}$ (Family size): It measures the number of people in the farmer's household who he/she is responsible for. The higher the family size the greater the need for an increased income and higher the tendency for the farmer to participate in export, so, therefore, it has a positive a-priori expectation.

$\mathbf{X}_{\mathrm{i10}}($ Other occupation): It measures the number of other occupations the farmer is involved in. if the farmer is involved in several other occupations that generate income for him/her there is a likelihood that the farmer will be less willing to participate in export. The a-priori expectation is negative.

$\mathbf{X j}_{1}$ (Geographical location of farmers' enterprise): It is a measure of the distance of farmers' farm from the nearest major transportation route. The a-priori expectation is negative because the more the distance the less willing the farmer is to export.

$\mathbf{X}_{\mathrm{j} 2}$ (Farm size): It measures the acreage of land the farmer brings under cultivation for growing yam. The higher the land acreage the more the farmer will be willing to export. The a-priori expectation is positive.

$\mathbf{X}_{\mathrm{j} 3}$ (Quantity consumed): It is a measure of the quantity of yam consumed from the quantity of yam harvested by the farmer. The a-priori expectation is negative, the higher the quantity of yam consumed by the farmer the less will be his willingness to export.

$\mathbf{X}_{\mathrm{j} 4}$ (Accessibility of transport facilities): It measures the frequency and ease with which means of transportation can deliver transport 
services to farmers. The a-priori expectation is positive.

Table 2 shows how the outputs from the respondents were converted to their weights equivalents. Following the steps of Kormawa and Ogundapo, 2004, yams are divided into 3 grades (sizes) and with their average weights. This was used to generate the outputs from each respondent in kilogram.

TABLE 2

Converting factors used in converting different sizes of yam (yam grades) to appropriate weight

\begin{tabular}{ll}
\hline Yam grades & Weight of yam $(\mathbf{k g})$ \\
\hline Grade 1 & 3.96 \\
Grade 2 & 2.19 \\
Grade 3 & 1.09
\end{tabular}

Source: Kormawa \& Ogundapo at International Institute of Tropical Agriculture (IITA), 2004

\section{Results and Discussions}

\section{Socioeconomic Characteristics}

Results showed that $33.8 \%$ of the farmers had a mean age of 65 years. This reveals that few of the farmers are growing old which is in agreement with the works of Izekor and Olumese (2010) and Aniedu et al. (2007). Also, $58.75 \%$ had their age between 21 and 40 years indicating that majority of yam farmers in the study area are still youths in their active age which is in contrast to the findings of Otegbayo et al. (2010). $87.5 \%$ of the respondents were males while $12.5 \%$ were female suggesting that yam business is a male-dominated business that also corroborates the previous findings of Izekor \& Olumese (2010) and Ayanwuyi et al. (2011). 36.3\% of the farmers in the study area have formal education while $91.3 \%$ are married which conforms to the findings of Aniedu et al. (2007) and Otegbayo et al. (2010). Also, 70\% have a large household size (mean 7.55, Std dev=2.98) which is in agreement with the work of Oboh \& Ekpebu (2011) and $88.8 \%$ indicated that they don't have the financial means to export.

Majority $(51.2 \%)$ of respondents in the study area indicated farming as their only occupation. $85 \%$ of the respondents have not adopted any yam production technologies on their farms. The adoption level was observed to be expectantly low probable because the farmers are now growing old (Patricia et. al., 2019). $100 \%$ of the respondents in the study area indicated that nothing in their belief prevents them from exporting.

\section{Result of determinants of factors affecting farmers' willingness to export yam.}

The result of the Probit analysis of factors affecting farmers' willingness to export yam is presented in Table 3. All the variables included in the model had positive effects on the farmers' willingness to export yam suggesting that an increase of $1 \%$ in these variables will have a proportionate effect on farmers' willingness to export yam based on the value of their coefficients. However, the level of education, family size, exportable surplus, availability of transport facilities, government restrictions, interest rate and cost of export had negative effects on willingness to export yam in the study area. This means an increase of $1 \%$ on any of these variables will bring about a corresponding decrease in yam farmers' willingness to export their produce.

Explicitly and considering the significant variables, farm size was positive and significant at $1 \%$. This means if the size of farmers' farm increases by 1 hectare, farmers' willingness to export will increase by 0.81 units. This confirms the a priori expectation that the larger the farm size the more willing the farmers are to export. In other words, farmers who own large farms, benefit from economies of scale, these farmers can make use of tractor 
instead of manual labour, and make relatively high profits enabling them to have the financial means to export and are therefore interested in the prospects of increasing their income from export since they can afford it. On the other hand, farmers with small farms are unlikely to benefit from economies of scale as such having relatively low income, therefore making export an uncompetitive venture for them. The quantity consumed was negative and not significant. This supports the a priori expectation that the higher the quantity consumed the less willing the farmer will be to export.

Concerning other variables, the availability of transport facilities and exportable surplus were negative and not significant which shows that farmers in the study area who had better access to transport facilities are unwilling to export. This contradicts the a priori expectation that the more the farmers have access to transport facilities, the more willing they would be to export. This probably can be due to the high cost involved in transportation which reduces their profit from the business. Also, it signals that when exportable surplus increases, willingness to export yam reduces. Other occupation of farmers had positive sign and not significant. This implies that it can improve willingness to export yam if it increases. This disagrees with the a priori expectation that farmers who had other occupation with other sources of income would be less willing to export. Farmers with other occupation are more interested in the additional income that could be generated from exporting and thereby are willing to export. This might have resulted from the fact that they have more money and can fund the exporting business.

TABLE 3

Result of the determinants of the factors affecting farmer's willingness to export yam in Oyo state

\begin{tabular}{lllll}
\hline Variables & Coefficients & Std. Error & $\mathbf{Z}$ & P - val \\
\hline $\mathbf{X}_{\mathrm{i}}=$ Personal Characteristics & & & & \\
& & & & \\
Constant & -5.476434 & 2.198993 & -2.49 & $0.013^{*}$ \\
$\mathrm{X}_{\mathrm{i} 1}=$ Age of farmer & .314 & .396 & 0.79 & 0,211 \\
$\mathrm{X}_{\mathrm{i} 2}=$ Sex & .024 & .103 & -0.24 & 0.153 \\
$\mathrm{X}_{\mathrm{i} 3}=$ Level of formal education & -.026 & .123 & -0.21 & 0.711 \\
$\mathrm{X}_{\mathrm{i} 4}=$ finance (N) & 0.349 & 0.521 & 0.67 & 0.241 \\
$\mathrm{X}_{\mathrm{i} 5}=$ Marital status, & 0.158 & 0.331 & 0.48 & 0.315 \\
$\mathrm{X}_{\mathrm{i} 6}=$ Family size (number) & -0.002 & 0.024 & -0.08 & 0.112 \\
$\mathrm{X}_{\mathrm{i} 7}=$ Personal belief & .110 & .122 & 0.90 & 0.442 \\
$\mathrm{X}_{\mathrm{i} 8}=$ Farming experience (years) & .054 & .110 & 0.49 & 0.312 \\
$\mathrm{X}_{\mathrm{i} 9}=$ Technological adoption & .152 & .137 & 1.11 & 0.119 \\
$\mathrm{X}_{\mathrm{i} 10}=$ Other occupation & .960700 & .673926 & -1.43 & 0.154 \\
$\mathbf{X}_{\mathrm{j}}=$ Farm Characteristics & & & & \\
$\mathrm{X}_{\mathrm{j} 1}=$ Geographical location of farm & .239 & .161 & 1.48 & 0.128 \\
$\mathrm{X}_{\mathrm{j} 2}=$ Farm size (hectares) & .809487 & .262157 & 3.09 & $0.002^{*}$ \\
$\mathrm{X}_{\mathrm{j} 3}=$ Exportable surplus per farmer (kg) & -.000038 & .000602 & -0.06 & 0.949 \\
$\mathrm{X}_{\mathrm{j} 4}=$ Availability of transport facilities & -.922022 & .735108 & 1.25 & 0.210 \\
$\mathrm{X}_{\mathrm{j} 5}=$ Storage facilities & .122 & .133 & 0.95 & 0.333
\end{tabular}


$\mathbf{X}_{\mathrm{k}}=$ Perceived Characteristics of Innovation

$\mathrm{X}_{\mathrm{k} 1}=$ awareness $\quad .195$

$\mathrm{X}_{\mathrm{k} 2}=$ profitability

$\mathrm{X}_{\mathrm{k} 3}=$ government restrictions

$\mathrm{X}_{\mathrm{k} 4}=$ exchange rates (N)

$\mathrm{X}_{\mathrm{k} 5}=$ interest rates (N)

$\mathrm{X}_{\mathrm{k} 6}=$ relative advantage

$\mathrm{X}_{\mathrm{k} 7}=$ contact with extension agents

$\mathrm{X}_{\mathrm{k} 8}=$ cost of exportation (

$\mathrm{X}_{\mathrm{k} 9}=$ risk and uncertainty

$\mathrm{X}_{\mathrm{k} 10}=$ ease of exporting

$\mathrm{X}_{\mathrm{k} 11}=$ availability of reliable agent/distributor .389

$\mathrm{X}_{\mathrm{k} 12}=$ ability to meet quality and quantity on

continuous basis

Source: Data analysis, 2013

\section{Conclusion}

It can, therefore, be concluded that yam producers in the study area would be willing to export yam if they have more land to produce yam in order to have more yams for the international market. In addition to this, other income-generating occupations can also be made available to these farmers aside from yam production. This study explicitly reveals that yam exportation in the study area would be positive with land availability and additional source of funding.

\section{REFERENCES}

Aderibigbe, S. O. \& Manson, N. (2018) Nigeria Agriculture Sector Performance Review. Technical Report, Nigerian Institute of Social and Economic Research (NISER).

Ana-Tavares, L. \& Diana, C. (2015) Performance differences between exporters and Non-Exporters: the case of Portugal, FEP-UP, School of Economics and Management, University of Porto

Aniedu, C., Nwachukwu I., Uwakah, C. T. \& Unamma, R. P. A. (2007) Gender factor influencing adoption of yam minisett technique in
South-eastern Nigeria: Implications for sustainable yam production. Journal of Agriculture and Social Research 7 (2), 30 - 37.

Adesiyan, O. F. (2011) Resource and Price competitiveness of yam production and consumption in Nigeria. An unpublished $\mathrm{PhD}$ these from the department of Agriculture, Obafemi Awolowo university, Ile-Ife. 1 - 196.

Ayanwuyi, E., Akinboye, A. O. \& Oyetoro, J. O. (2011) Yam production in orire local government area of Oyo state, Nigeria: farmer's perceived constraints. World J Young Researchers 1 (2), $16-19$.

Bangmarigu, E. \& Artan, Q. (2018) Cocoa production and Export in Ghana.

A Paper prepared for presentation for the 162nd EAAE Seminar, The evaluation of new CAP instruments: Lessons learned and the road ahead, Corvinus University of Budapest, Hungary

Bernard, A. B., \& Jensen, A. B. (1995) Exporters, jobs, and wages in U.S. manufacturing: 19761987. Brookings Paper on Economic Activity, $67-112$. 
Bernard, A.B., \& Jensen, A. B. (1999) Exceptional exporter performance: cause, effect, or both? Journal of International Economics 47, 12 5.

Bernard, A.B., \& Jensen, A. B. (2004b) Why some firms export? Rev. Econ. Statist. 86: 561 569.

Bernard, A. B., Jensen, J. B., Redding, S. J. \& Schott, P. K. (2007) Firms in international trade. Journal of Economics Perspective 21, $105-130$.

Bliss, C.I. (1934) The Method of Probits. Science 79 (2037), 38 - 39. DOI: 10.1126/science.79.2037.38.

Cisko, Š., \& Klieštik, T. (2013) Finančný manažment podniku II. Žilina: EDIS Publisher.

Clerides, S. K., S. Lach, \& Tybout, J. R. (1998) Is learning by exporting important? micro-dynamic evidence from Colombia, Mexico, and Morocco. Quarterly Journal of Economics 113, 903 - 947 .

Ekpo, A. \& Egwaikhide, F. (1994) Exports and economic growth in Nigeria: A reconsideration of the evidence: Journal of Economic Management 1 (1), $100-115$.

Food and Agriculture Organisation (2019) www. fao.org/faostat/en/\#home

Gaddum, J. H. (1933) Reports on Biological Standard III. Methods of Biological Assay Depending on a Quantal Response. London: Medi-cal Research Council. Special Report Series of the Medical ResearchCouncil, no. 183.

Girma, S., D. Greenaway, \& Kneller, R. (2004) Does exporting increase productivity? A microeconometric analysis of matched firms. Review of International Economics 12, 855 - 866.

Inside Tax (2015) Export Promotion Incentives: Is Nigeria running on the spot? Deloitte. 1. https:// www2.deloitte.com/content/dam/Deloitte/ng/
Documents/tax/inside-tax/ng-export-promotion-incentives.pdf

International Conference on E-Business and E-Government (2010) IEEE Xplore https:// ieeexplore.ieee.org/document/5591968.

Izekor, O. B. \& Olumese, M. I. (2010) Determinants of yam production and profitability in Edo State, Nigeria. African Journal of General Agriculture 6 (4), $205-210$.

Kollár, B. (2014) Credit Value at Risk and Options of Its Measurement. 2nd International Conference on Economics and Social Science (ICESS 2014), Information Engineering Research Institute, Advances in Education Research 61, $143-147$.

Kormawa, P. \& Ogundapo, A.T. (2004) Local weights and measures in Nigeria: A handbook of conversion factors. IITA Monograph. Ibadan, Nigeria: International Institute of Tropical Agriculture

Lehutová, K. (2011) Application of Corporate Metrics method to measure risk in logistics. International Scientific Conference Computer systems aided science industry and transport, $2209-2213$.

Lindblom, J., Lundström, C., Ljung, M. \& Anders, J. (2017) Promoting sustainable intensification in precision agriculture: review of decision support systems development and strategies. Precision Agriculture 18 (3), 309 -311 .

Majerčák, P., \& Majerčáková, M. (2013) The enterprise valuation and categories of the value. Financial management of firms and financial institutions, $469-475$.

Nimoh, F. (2011) Investigating the interest of farmers and insurance companies in farm insurance: The case of cocoa farmers in Sekyere West Municipal of Ghana. Journal of Agricultural Science 3 (4), 126 - 135.

Oboh, V. U. \& Ekpebu, I. D. (2011) Determinants 
of formal agricultural credit allocation to the farm sector by arable crop farmers in Benue State, Nigeria. African Journal of Agricultural Research 6 (1), $181-185$.

Okwu, A. T., Dada, S. O., \& Owolabu, S. A (2013) A comparative Analysis of Export Promotion Strategies in Selected African Countries (South Africa, Nigeria and Egypt), International Journal of Management Sciences 1 (6), 204 -211 .

Otegbayo, B. O., Samuel, F. O., Kehinde, A. L., Sangoyomi, T. E. \& Okonkwo, C. C. (2010) Perception of food quality in yams among some Nigerian farmers. African Journal of Food Science 4 (8), 541 - 549.

Patricia, P. A., Danquah, E. O., Hashini, G. D., Hayford, P. \& Weebadde, C. (2019) A Socioeconomic Study of Transition Zone Yam Farmers Addressing Constraints and Exploring Opportunities for Integrating Pigeonpea into Yam Cropping Systems. Sustainability 11, $717-730$.

Pius, C. I. \& Odjuvwuederhie, E. I. (2006) Determinants of yam production and economic efficiency among small-holder farmers in Southeastern Nigeria. Journal of Central European Agriculture 7 (2), 337 - 342.

Sandro, S. (2014) Understanding logistic regression analysis. Biochemia Medica 24 (1), 12 - 18. doi: $\underline{\text { 10.11613/BM.2014.003 }}$

Stephen, M. (2018) Analysis of Yam Minisett technique adoption in Nigeria. Journal of Crop Improvement 32 (4), $511-531$.

Stock, J.H. \& Watson, M. W. (2006) Forecasting with many predictors. In G. Elliot, C.W.J. Granger, and A. Timmermann, editors, Handbook of Economic Forecasting, 515 - 554. Elsevier, Amsterdam.

Trading Economics (2019) https://tradingeconomics. com/nigeria/gdp-from-agriculture.

Xu, J. \& Long, J. S. (2005) Confidence intervals for predicted outcomes in regression models for categorical outcomes. The Stata Journal 5, $537-559$.

World Bank (2017) Rwanda Economic Update: Sustaining Growth by Building on Emerging Export Opportunities, $21-36$. 